\title{
The Purification of Semantic Environments and Des's Process of Moral Growth in Lionel Asbo: State of England
}

\author{
Wenju Han \\ College of Foreign Languages and Literature, Northwest Normal University, Lanzhou, China
}

\begin{abstract}
Martin Amis's new novel Lionel Asbo: State of England (2012) is a reflection and criticism of the pollution of the semantic environment. It's a satire of the media and celebrity culture in the capitalist society. From the perspective of media ecology, this paper studies the purification of the semantic environment which leads to the protagonist Des's moral growth. Initially, Des is immoral, for he lives in the polluted semantic environment of Diston. With the purification of semantic environment by traditional culture in the public library, Des gets moral growth and rises from darkness. His obsession with good books and serious newspapers leads to his moral growth. Through seeking knowledge, Des achieves his self-perfection, and helps the improvement of the society by becoming a crime reporter for a national newspaper the Daily Mirror and writes about law and order to guide people.
\end{abstract}

Index Terms-Martin Amis, Lionel Asbo: State of England, media, semantic environments, moral growth

\section{INTRODUCTION}

Martin Amis's new novel Lionel Asbo: State of England (2012) is a reflection and criticism of the pollution of the semantic environment. It's a satire of the media and celebrity culture in the capitalist society. Reviews are numerous after its publication. Robson (2012) argues that the theme of Lionel Asbo "is about the criminal law [. . .]. Desmond, who has committed statutory rape by having an affair with his 39-yearold grandmother, becomes a crime reporter" (p. 45). And he points out that "the novel is also concerned with other symptoms of social decay - with single mothers and gang violence and all those things that have been much on Amis's mind" (Robson, 2012, p. 45). The critic Tait classifies it as a "satire, Shakespearean romance or pornotheological farce" (2012). "It's a familiar line of attack against unearned wealth and celebrity, vulgarity, fake tits, feckless chavs, slipping educational and moral standards" (Tait, 2012). "Lionel Asbo is going to be a clueless foray into popular culture and working-class life" (Tait, 2012). With the subtitle "State of England", "decrying the country's 'moral decrepitude', it is a full-on indictment of a debased culture" (Tait, 2012). These critics point out the novel's criticism on the debased culture and degraded morality, but they neglect the cause-and-effect relationship between the media cultural environment and moral change.

From the perspective of media ecology, this paper studies the purification of the semantic environment which leads to moral growth in Lionel Asbo: State of England. Media ecology not only studies the informational devices such as the radio, newspaper, television, movies, sound records, the computer, but it also "looks at how the symbolic structure of environments - such as social environments - may define human interaction or the production of culture" (Lum, 2006, p. 31). Media work as the semantic environments in which people live in. Postman (1969) defines "a semantic environment as any human situation in which language plays a critical role" (Postman et al., p. 15). Nowadays, we become more and more dependent on the media, which provides guidance to our social and private life. It especially sheds great influence on morality. A fundamental concept in media ecology is: "that media are environments, and that consequences arise when there are problems in these environments" (Gencarelli, 2006, p. 210). To ensure the long-lasting survival of human beings, a healthy semantic environment should be created, an ecological balance in our semantic environment should be kept.

In the postmodern era in the Western society, drastic changes are taking place, yet religion declines. The death of God not only destroys people's indoctrinated paradigm to understand the world, but also obscures the meaning of human existence (Zhao, 2006, p. 105). Therefore, people rely on the mass media to understand the world. Mass media begin to play the role of the secular god. People turn to media for the meaning and value of life, the ways of living and thinking to guide them, so media play an important role in constructing their behavior and morality. The protagonist in Lionel Asbo: State of England, Desmond Pepperdine, has no one to guide him morally, so he turns to the tabloid The Morning Lark for advice, and the columnist offers guidance to people confronting ethical dilemmas and shapes their moral values.

With the purification of semantic environment by traditional culture, Des gets moral growth and rises from darkness. With the decline of religion in Western society, Matthew Arnold (1970) resorts to culture as the force of salvation. "Culture" has many definitions in different backgrounds and subjects. And he defines culture as "the best that has been known and thought in the world" (p. 154-55). It is culture that distinguishes human beings from animals. Culture is the 
basis of people's physical and mental health. And it is the carrier and backbone of people's belief. Because the electronic revolution of communication produces a vast amount of information garbage, pollutes the semantic environment and trivializes culture, Postman proposes to preserve culture through education, which is also Martin Amis's idea proposed in Lionel Asbo: State of England through portraying a moral idol - Des. His obsession with good books and serious newspapers leads to his moral growth. Through seeking knowledge, Des achieves his self-perfection, and helps the improvement of the society. At last, he becomes a "tall, slender, well spoken and delightfully assured young man, a graduate of Queen Anne's college, London" (Amis, 2012, p. 150). He shows civility in dealing with people. And he is intelligent. He speaks "with gorgeous smile and the light of true intelligence in his hazel eyes" (Amis, 2012, p. 151), presenting a sharp contrast to the pathetic gropings of his poor old uncle Lionel. He has got a mature self to face the challenge and surmount it. Martin Amis highly approves of him. 'It's young Des Pepperdine who's achieved something in this life. It's young Des Pepperdine who's 'come good'. 'Not Lionel Asbo"' (Amis, 2012, p. 152). He is saved by education, and goes through a process of moral development.

\section{Des's Initial Immorality Caused By the Polluted Semantic EnVironment}

In the beginning, Des is immoral, for he lives in the polluted semantic environment of Diston. "The most important forces that shape our moral development are the family, peer groups, role models, and institutional forces play an increasingly significant role in shaping our moral destiny" (Day, 2000, p. 20). His family and peer groups shed negative influence on his moral development. He has no sense of morality. After the incest, "it isn't the morality of doing it with granny that bothers the boy, Des Pepperdine, he's more concerned about what his uncle, the uber-chav Lionel Asbo ('Anti-Social Behaviour Order')" (Adiga, 2012, p. 1). Des is not bothered by morality, but by the legal question and fear for his uncle. "Apart from the legal question which is worrying me sick, theres another huge problem. Her son, Lionel is my uncle, and hes' like a father to me when he's not in prison. See hes an extremely violent criminal and if he find's out I'm giving his Mum one, hell fucking kill me. Literally" (Amis, 2012, p. 5). Morality is of little concern to the people in Diston, violence is their first policy to deal with trespass. Because of his incest with his granny Grace, Lionel kills his classmate Rory Nightingale, who becomes the scapegoat of Des. He is the only child of $\mathrm{Mr}$ and $\mathrm{Mrs}$ Nightingale who loves each other tenderly. They are a happy family, but his death brings tragedy to the family.

At the very start, Des has low literacy level because of his humble origin. In his letter addressing to a tabloid editor Jennaveieve for help, there are some mistakes in the spelling of words, e.g., he misspells "always" as "allways", grammatical errors (e.g., [. . .] Uncle George whose in the trade), and punctuation mistakes ([. . .] it's the plumbing again love, no punctuation between "again" and "love".).

Des's family has a negative impact on his moral development. Acting as the father of Des, Lionel instructs false values to him. He is against Des's studying; he abuses Des for buying a dictionary instead of buying food for the dog. In his opinion, stealing is a proper business. He tells Des to "do something useful. Steal a car" (Amis, 2012, p. 8). He admonishes Des to carry a blade when he goes out at night. "For you own security. And you peace of mind. You going to get youself striped. Or worse. There's no fistfights any more, not in Diston. There's only knife fights. To the death. Or guns" (Amis, 2012, p. 9). Besides, Lionel persuades Des to concentrate on Internet porn. He lends his computer to Des to access pornography. "In common with every other Distonite old enough to walk, Des knew about the existence of pornography on the Web. He had never gone looking for it" (Amis, 2012, p. 23). He has no interest in the pornography on the Internet, "he put the Web aside, reached for the Cloud, and started learning about calligraphy" (Amis, 2012, p. 24).

In addition, Des's peer group sheds a harmful effect on him in morality. The school Des attend, Squeers Free, is the worst school in England. As its name suggests, it's a school where the students enjoy undisciplined freedom. It is also a place of social and moral decay. It shows desolation. Actually, it is a hotbed for juvenile delinquency.

School - Squeers Free, under a sky of white: the weakling headmaster, the demoralized chalkies in their rayon tracksuits, the ramshackle little gym with its tripwires and booby traps, the Lifestyle Consultants (Every Child Matters), and the Special Needs Coordinators (who dealt with all the 'non-readers'). In addition, Squeers Free set the standard for the most police call-outs, the least GCSE passes, and the highest truancy rates. It also led the pack in suspensions, expulsions, and PRU 'offrolls'; such an offroll - a transfer to a Pupil Referral Unit was usually the doorway to a Youth Custody Center and then a Young Offender Institution. (Amis, 2012, p. 19)

Students live by the jungle law in Squeers Free. School bullying is frequent and grave. The well-behaved, the swats, wimps, four-eyes, sweating fatties and physically weak students are "savagely bullied - to the brink of suicide and beyond" (Amis, 2012, p. 20). Des is incompatible with his peer group. "Des was a prime candidate for persecution. He seldom bunked off, he never slept in class, he didn't assault the teachers or shoot up in the toilets - and he preferred the company of the gentler sex (the gentler sex, at Squeers Free, being quite rough enough)" (Amis, 2012, p. 20). Des is called Skiprope and Hopscotch, but he isn't bullied actually inviolable for he is the nephew and ward of Lionel Asbo. What is feared in Diston is not law but violence. Social order is defied. Students who obey the social order are considered as misfits, the school is replete with violence and moral decay. Most students become criminals at school. Lionel has followed the route. "(He) always spoke of his five and a half years (on and off) in a Young Offender Institution (or Yoi, as he called it) with rueful fondness, like one recalling a rite of passage - inevitable, bittersweet. I was out for a month, he would typically reminisce. Then I was back up north. Doing me Yoi" (Amis, 2012, p. 19). Des's 
peer group does harm to his moral development. He lives in a "tunnel” (symbolizing darkness), but he doesn't fall because he is keen on serious culture. He fancies modern languages, history, sociology and astronomy.

\section{Des’s Moral Growth with the Purification of the Semantic EnVIRONMENT}

Under the institutional influence and obsession with good books and serious newspapers, Des rises from darkness. 'Des's redemption issues from different institutions: university and matrimony. [. . .], education appears to Des as the 'harmony of the cosmos,' and his dedication to self-improvement grants him passage to a coherent world where his ability to love wins him a woman of good character" (Harrison, 2012, p. 8). Amis couldn't resist a name that carries meaning, as the name of Des's wife, Dawn suggests, Des finds salvation at last. "Des, emerging from darkness, arrives at Dawn" (Harrison, 2012, p. 8).

Although living in darkness, Des has interest in learning. His role model is his grandfather. He studies Economics at the University of Manchester. Des reveres the university and he always murmurs the word. To Des, university is "the one poem", "the harmony of the cosmos...And he wanted it" (Amis, 2012, p. 13).

Des is called a "Renaissance Boy". Through him, Martin Amis dramatizes the salvation of the debased culture by reviving traditional culture and the Victorian values. "Pepperdine is working himself up the social ladder in a very Victorian way: by improving his spelling and punctuation, attending university and becoming a father" (Adiga, 2012, p. 30). He is dedicated to self-improvement through culture. "His handwriting, nowadays, was self-consciously elegant; the letters used to slope backward, but he patiently trained them to slope forward; and when everything was smoothly conjoined he started adding little flourishes (his e was positively ornate-like a w turned on its side)" (Amis, 2012, p. 3). And he takes courses on calligraphy and punctuation. He has mastered calligraphy, sociology, anthropology and psychology.

He is anxious for knowledge. He is conscious of his ignorance, so he is eager to get an education. "He was trying to give himself an education - not at Squeers Free, recently singled out, [. . .], as the worst school in England. But his understanding of the planet and the universe had inconceivable voids in it. He was repeatedly amazed by the tonnage of what he didn't know" (Amis, 2012, p. 4).

He is prudent in his studying of punctuation. Des studies very hard on the usage of each punctuation. "The main role of the semicolon', he read in his Concise Oxford Dictionary, 'is to mark a grammatical separation that is stronger in effect than a comma but less strong than a full stop" (Amis, 2012, p. 14). He cherishes the Concise Oxford Dictionary. "Des had the weight of the book on his lap. It was his prize possession. Its paper jacket was royal blue ('deep, vivid')" (emphasis in the original) (Amis, 2012, p. 14).

The public library opens the road to his salvation. He goes into the Public Library on Blimber Road with hesitation, and with deafening self-consciousness. "Squeers Free had a library, of course, a distant Portakabin with a few primers and ripped paperbacks scattered across its floor...But this: rank upon rank of proud-chested bookcases, like lavishly decorated generals" (Amis, 2012, p. 21). He is drawn by the grandeur of the atmosphere in the library. "He entered the Reading Room, where the newspapers, firmly clamped to long wooden struts, were apparently available for scrutiny. No one stopped him as he approached" (Amis, 2012, p. 21). Accustomed to reading tabloids such as the Morning Lark and Diston Gazette, he is scared of serious newspapers. "Respectfully averting his eyes from the Times, the Independent, and the Guardian, Des reached for the Sun, which at least look like a Lark, with its crimson logo and the footballer's fiancée on the cover staggering out of a nightclub with blood running down her neck" (Amis, 2012, p. 21). The Sun bears some resemblance to the tabloids Des often reads, but it has some news report. "And, sure enough, on page three (News in Briefs) there was a hefty redhead wearing knickers and a sombrero. But then all resemblances ceased. You got scandal and gossip, and more girls, but also international news, parliamentary reports, comment, analysis" (Amis, 2012, p. 21). Des comes to the truth that compared with the Sun, the Lark he trusts so much in the past is in fact "a daily lads" mag, perfunctorily posing as a journal of record" (Amis, 2012, p. 21).

Des gets moral purification in the Public Library on Bimber Road, which quenches his restlessness in the noisy and chaotic urban environment. "On the streets of Cairo the ambient noise, scientifically averaged out, was ninety decibels, or the equivalent of a freight train passing by at a distance of fourteen feet (the ambient noise caused partial deafness, neuroses, heart attacks, miscarriages)" (Amis, 2012, p. 33). In the silence in the library, he finds peace of mind. The library is such a quiet place that he could hear himself cough, sigh, breathe and hear the sound of the points and junctions of his own sinuses. "He made straight for the radiant Reading Room with its silvery motes of dust. First, naturally, he wrenched open the Sun" (Amis, 2012, p. 34). He comes directly to the international news on it. And he accesses more serious newspapers such as the Independent and the Times here. "After a look over his shoulder, he reached out an unsteady hand for the Independent (which was at least recognizably tabloidal in size). He expected the spidery print to exclude him. But it didn't; it let him in..." (Amis, 2012, p. 35). "Des read all the international news in the Independent, and then moved on to the Times. [. . . He had spent eight hours in the place called World" (Amis, 2012, p. 35). The serious newspapers connect him to the outside world and broaden his knowledge and understanding of the world. The serious newspapers and books nurture Des's sense of social responsibility. He begins to talk about international affairs with his uncle Lionel, who shows little concern in contrast.

Under the enlightenment of serious culture, Des forms a healthy relationship with others and the society. He visits his granny Grace every day. After Grace is sent to a famously desolate home for the old, he keeps on visiting her, though he 
has to take two days' hard trip. "You rose before first light (Inverness, then motorcoach via Lairg), and you returned in the next day's early darkness: the grey hours. Des did his Christian duty, and his Christian penance, about every six weeks, and sometimes Dawn came too" (Amis, 2012, p. 130). He visits Lionel at prison regularly. Bothered by a guilty conscience, he calls on Rory's (who is killed by Lionel as a scapegoat of Des's incest with his granny Grace) parents, Joy and Ernest, and helps them run errands. The Nightingales get comfort from Des who fills the space of their son. After he becomes a reporter of the Daily Mirror, he frightens Lionel to move his granny Grace to a better place with his wisdom. "Des pictured it: a Shock Issue of the Daily Mirror, on Gran's home. 'You on your lounger by the pool. Grace strapped to her mattress in the attic. Could make it look bad"' (Amis, 2012, p. 164). For fear of damaging his image as a public figure, he agrees with Des's suggestion.

He has good performance at school.

In 2006 he sat his GCSEs - and got eleven A's! He was transferred, on the Gifted Programme, to Blifil Hall, where, in 2007, he sat his A-levels - and picked up four distinctions! He was sixteen. Next, he was offered a provisional place (he would have to survive the interview) at Queen Anne's College! Queen Anne's College of the University of London. (Amis, 2012, p. 57)

Finally, he gets admitted into the university.

Des not only achieves self-perfection through attending university, but begins to prompt the perfection of the society. "Des switched subjects: from Modern Languages to Sociology, with a special emphasis on crime and punishment" (Amis, 2012, p. 131), to uphold justice with his efforts. He and Dawn study hard and both get Two Ones. After graduation, he becomes a crime reporter for a national newspaper the Daily Mirror and writes about law and order.

In addition to books and serious newspapers, Des gets his redemption from matrimony. Before he comes to university, he has casual sex with many girls. "Des continued, off and on, to see a fair bit of Alektra, then a fair bit of Jade, then a fair bit of Chanel" (Amis, 2012, p. 57). "And then, in 2008, when he went for his interview at Queen Anne's College, Des met Dawn Sheringham, and everything changed" (Amis, 2012, p. 58). "She was the only one present who was doing something sensible: she was reading (he stole a glance - The Golden Bough)...The rest of them, Des included, were merely helplessly and dumbly waiting, like patients waiting for the doctor's nod" (Amis, 2012, p. 62). They go out hand in hand, "with books on their laps. Dawn was reading Jessie Hunter ${ }^{1}$. Des was reading Emile Durkheim" (Amis, 2012, p. 70). They read books on literature and philosophy. "Holding hands. Books on their laps. Kisses. Civilization, thought Des Pepperdine" (Amis, 2012, p. 70). He has been with Dawn for fourteen months, but they just hold each other, have no sex. They develop pure love and healthy relationship.

Des earns money by legal means. He has applied the Assistance and done part-time jobs in his spare time. "Six nights a week, therefore, from seven to midnight (and all day Sunday), Des minicabbed for Goodcars" (Amis, 2012, p. 69). He works hard to support himself and his family.

In the end, Des becomes a reporter for a national newspaper, sets a happy family with Dawn and fathers a child. He gets success and redemption through print literacy. He reaches the "absolute inward peace and satisfaction which are reached as we draw near to complete spiritual perfection, and not merely to moral perfection, or rather to relative moral perfection" (Arnold, 1984, p. 55). Amis highly approves of Des's interest in learning, because an interest in learning is a key to improve oneself and the society. Through Des, Amis expresses his thought as a social ameliorist, as he said in an interview, "I like the idea of coming up with a society that is a little better than this - a gradualist, ameliorist spirit getting something a little fairer and a little more compassionate" (Wallace, 2012, p. 8). Through the example of Des, Martin Amis proposed the advice to solve the moral and social decay by providing a good education. Des's interest in learning ensures him a university education, a good job, a happy marriage and healthy interpersonal relationships. The purification of his semantic environment by serious culture prompts his moral growth. Des not only achieves self-perfection, but begins to prompt the perfection of the society through his work as a reporter.

\section{CONCLUSION}

To sum up, in the novel, the tabloids such as the Diston Gazette, the Morning Lark, the Sun, TV and the Internet dominate people's spiritual life in Diston. They are filled with violence, sexually explicit content and the private lives of the social luminaries. They produce a vast amount of garbage which pollutes the semantic environment, and create a cultural environment which breeds incest, sexual freedom and gang violence in Diston. And they turn many entertainers such as the "Lotto Lout" Lionel, the glamour model turned poet Threnody into public figures. Lionel Asbo shows anti-social behavior, anti-culture, anti-intellectualism, anti-morality and indifference to people, but he gets effortless success and admiration from the media and the mass, sets a morally bad example for people, leading to their moral ambiguity. Besides, the characters' addiction to the virtual media environment causes their self-exclusion and indifference to others, impedes them from forming healthy moral relationships with others in reality. The pollution of semantic environment breeds moral decrepitude and debased culture, which partially explains the decline of the British

\footnotetext{
${ }^{1}$ Jessie Hunter is an American novelist. She has published novels such as Blood Music (1993), One, Two, Buckle my Shoe (1997), The Green Muse (2015).

${ }^{2}$ Emile Durkheim (1858-1917) is a French philosopher. His eminent works are The Division of Labor (1893), The Rules of Sociological Method (1895), Suicide (1897), The Elementary Forms of the Religious Life (1912) and so on. See Bierstedt, Robert. Emile Durkheim. New York: Dell Publishing Co., 1966.
} 
Empire. Martin Amis is not totally despaired over the situation; he thinks that the solution lies in the renaissance of traditional culture through education and the conservation of print literacy. And he expresses his idea as a social ameliorist by portraying the moral idol Des. Reading serious books and newspapers purifies his semantic environment and leads to his moral growth. At last, he gets salvation. He grows into a moral ideal, gets a decent job which is beneficial to the society and has a happy family.

\section{REFERENCES}

[1] Adiga, A. (2012). In a tale of moral decline and urban decay lies hope for the true believers. Rev. of Lionel Asbo: State of England by Martin Amis. Sydney Morning Herald [Sydney] 14 July: 30.

[2] Amis, M. (2012). Lionel Asbo: State of England. London: Jonathan Cape.

[3] Arnold, M. (1984). Culture and Anarchy. Ed. J. Dover Wilson. 1932. Cambridge: Cambridge UP.

[4] Arnold, M. (1970). Selected Prose. Ed. P. J. Keating. New York: Penguin Books.

[5] Day, L. A. (2000). Ethics in Media Communications: Cases and Controversies. $3^{\text {rd }}$ ed. Ontario: Wadsworth Thomson Learning.

[6] Gencarelli, T. F. (2006). Neil Postman and the Rise of Media Ecology. In C. M. K. Lum (Ed.), Perspectives on Culture, Technology and Communication: The Media Ecology Tradition (pp. 201-53). New Jersey: Hampton Press.

[7] Harrison, K. (2012). Lottery Lout. Rev. of Lionel Asbo: State of England by Martin Amis. New York Times 19 Aug: $1+$.

[8] Lum, C. M. K. (Ed.). (2006). Perspectives on Culture, Technology and Communication-The Media Ecology Tradition. New Jersey: Hampton Press.

[9] Postman, N., Charles W., \& Terence P. M. (Eds.). (1969). Language in America: A Report on our Deteriorating Semantic Environment. Indianapolis, New York: Pegasus.

[10] Robson, L. (2012). How Late it Was, How Late: Martin Amis's Changing Vision of London. Rev. of Lionel Asbo: State of England by Martin Amis. New Statesman 11 June: 44+.

[11] Tait, T. (2012). Is this satire, Shakespearean romance or pornotheological farce? The Gardian 8 June. Retrieved Feb. 19, 2018, from https://www.theguardian.com/books/2012/jun/08/lionel-asbo-martin-amis-review.

[12] Wallace, W. D. (2012). In Conversation: Martin Amis. New York 30 July: 45. (22) Retrieved Jan. 28, 2018, from https://search.proquest.com/docview/1027388847?OpenUrlRefId=info:xri/sid:primo\&accountid=13814.

[13] Zhao Y. F. (2006). Hai de ge er: yi shu he yu yan [Heidegger: Art and Language]. Foreign Literature, 3, 100-110.

Wenju Han was born in Lanzhou, China, in 1986. She received his PH.D. degree in English Language and Literature from Shanghai International Studies University in Shanghai, China in 2018.

She is currently a lecturer in the College of Foreign Languages, Northwest Normal University, Lanzhou, China. She has conducted one research project funded by Gansu province in China: An Investigation of the Present Situation of the Boarding Schools in the Rural Minority Areas and Corresponding Countermeasures-Taking Gannan Tibetan Autonomous Region as an Example. She has published twelve articles, such as The Art of Parody in Salman Rushdie's Midnight's Children (Taiyuan: Journal of Taiyuan Urban Vocational College, 2009), The Effectiveness of Grammar-translation Method in the Teaching of British and American Literature (Lanzhou: Journal of Gansu Normal Colleges, 2011), Construction and Deconstruction of Imagined Community-A Comparative Study of Daniel Defoe's Robinson Crusoe and J. M. Coetzee's Foe in Light of Nationalism (Journal of Language Teaching and Research, 2017). Her research interests include English education and British and American literature. 